\title{
TGM7 Gene
}

National Cancer Institute

\section{Source}

National Cancer Institute. T GM7 Gene. NCI Thesaurus. Code C150342.

This gene is involved in the conjug ation of polyamines to and cross-linking of proteins. 